\title{
Peran Teori Keadulatan Tuhan pada Perang Kediri dan Tumapel pada Pembentukan Hukum di Indonesia
}

\author{
Sarip ${ }^{凶}$ \\ Fakultas Hukum Universitas Muhammadiyah Cirebon \\ E-mail: sarip@umc.ac.id
}

\begin{abstract}
The sovereignty of God in the state administration of the Kingdom of Indonesia can be seen from the words of Ken Arok attacking the kingdom of Kediri, "O Pastors who adhere to Shiva and Buddhism. Please bless me to have the title Bhatara Guru ". The study of God's sovereignty can be clearly seen from the history of Ken Arok, who was the king of Tumapel, who succeeded in using God's sovereignty to gain power over Kediri. So the question is the extent to which the existence of the struggle for God's sovereignty in Indonesia which underlies divine values. Ken Arok as the ruler of Tumapel who is a subordinate of Kediri has committed an offense of royal state order. What was done by Ken Arok in terms of International Law as "belligerent". Ken Arok's movement to gain power by committing offenses on the state administration of the kingdom, legalized by the laws of the royal state at that time, as well as international law today. In addition to evidence of the theory of God's sovereignty which was applied by Ken Arok to strengthen his power, in modern times too, the theory of God's sovereignty was practiced by Soekarno during the Old Order. As proof of the theory of God's Sovereignty during the Soekarno era came from the minister of religion of the Republic of Indonesia who at that time was held by Wahid Hasyim, who considered it important to build a magnificent mosque as gratitude for Indonesia's independence in the struggle against the invaders.
\end{abstract}

Keywords: sovereignty, God, struggle, kingdom.

\begin{abstract}
Abstrak
Kedaulatan Tuhan dalam ketatanegaraan Kerajaan Indonesia dapat dilihat dari perkataan Ken Arok menyerang negara Kerajaan Kediri "Wahai para Pendeta pemeluk Siwa dan Budha. Restuilah Aku untuk bergelar Bhatara Guru". Penelisikan kedaulatan Tuhan pada dasarnya secara gamblang dapat dilihat dari sejarah Ken Arok yang merupakan raja Tumapel telah berhasil menggunakan kedaulatan Tuhan untuk mendapatkan kekuasaan atas Kediri. Maka yang menjadi pertanyaan sejauhmana eksistensi pergumulan kedaulatan Tuhan di Indonesia yang mendasari nilai-nilai ketuhanan.Ken Arok sebagai penguasa Tumapel yang merupakan bawahan dari Kediri telah melakukan delik tata negara kerajaan. Apa yang dilakukan oleh Ken Arok dalam istilah Hukum Internasional dengan sebutan "belligerent". Gerakan Ken Arok untuk mendapatkan kekuasaan dengan cara melakukan delik tata negara kerajaan, dilegalkan secara hukum negara kerajaan pada saat itu, maupun Hukum Internasional masa sekarang. Selain bukti teori kedaulatan Tuhan yang diterapkan oleh Ken Arok untuk memperkuat kekuasaannya, di jaman modern juga, teori kedaulatan Tuhan dipraktikan oleh Soekarno semasa Orde Lama. Sebagai bukti teori Kedaulatan Tuhan pada masa Soekarno datang dari menteri agama Republik Indonesia yang pada saat itu dijabat oleh Wahid Hasyim, yang menganggap penting dibangun Masjid megah sebagai rasa syukur atas kemerdekaan Indonesia dalam perjuangan melawan penjajah.
\end{abstract}

Kata kunci: kedaulatan, Tuhan, pergumulan, kerajaan.

Copyright@2020KosmikHukum. All rights reserved.

\section{Pendahuluan}

Undang-Undang Dasar 1945 sebagai norma dasar tertinggi negara (ground norm) menganut beberapa kedaulatan sekaligus, sebagaimana diungkapkan Ismail Sunny bahwa UUD 1945 menganut tiga ajaran kedaulatan sekaligus yaitu ajaran kedaulatan Tuhan, 
kedaulatan rakyat, dan kedaulatan hukum. ${ }^{1}$ Kedaulatan Tuhan dalam ketatanegaraan Kerajaan Indonesia dapat dilihat dari sejarah Ken Arok pada saat akan menyerang negara Kerajaan Kediri "Wahai para Pendeta pemeluk Siwa dan Budha. Restuilah Aku untuk bergelar Bhatara Guru". ${ }^{2}$ Perkataan Ken Arok bukti nyata tentang adanya kedaulatan Tuhan yang tidak dapat dilepaskan dari pemikiran ketatanegaran kerajaan hingga lahirnya Republik Indonesia.

Kedaulatan Tuhan dianggap sebagai teori pertama dalam sejarah ketetanegaraan. Kedaulatan Tuhan memiliki peran yang sangat signifikan dalam memperoleh kekuasaan terlihat dari jaman ketatanegaraan kerajaan sampai pada ketatanegaraan modern. ${ }^{3}$ Kedaulatan Tuhan mengilhami pengakuan akan Tuhan dalam ketatanegaraan Indonesia sampai sekarang. Hal ini tidak luput dari pandangan akan adanya kekuatan yang mengendalikan manusia itu sendiri.

Pembahasan nilai ketuhanan ketatanegaraan modern Indonesia bertolak pada sisi agama yang coba diasingkan pada masa penjajahan Belanda. Di zaman penjajahan Belanda (Hindia Belanda) diadakan pembedaan golongan-golongan rakyat. Tahun 1848, pembedaan golongangolongan rakyat di Hindia Belanda ditetapkan dalam Pasal 6 - 10 Algemene Bepalingen van Wetgeving. Menurut Soepomo peraturan ini membedakan isi negeri dalam dua golongan pokok, yaitu orang Eropah dan Bumiputera. Siapa saja yang termasuk orang Eropah dan siapa saja yang termasuk orang Bumiputera tidak dijelaskan dalam peraturan tersebut. Penggolongan itu dianggap sudah diketahui. ${ }^{4}$ Melihat sejarahnya pembahasan kedaulatan Tuhan dalam pembentukan ketatanegaraan Indonesia dilihat dari tahun diawali pada tahun $1602-1800 \mathrm{M} .^{5}$

Sila Pertama Pancasila "Ketuhanan Yang Maha Esa", ditegaskan kembali dalam UUD 1945 Bab XI tentang Agama Pasal 29 Ayat (1) "Negara berdasar atas Ketuhanan Yang Maha Esa", Ayat (2) "Negara menjamin kemerdekaan tiap-tiap penduduk untuk memeluk agamanya masing-masing dan untuk beribadat menurut agamanya dan kepercayaannya itu". Sangat disayangkan argumentasi-argumentasi hanya menyuguhkan ego agama masing-masing, bahkan belum ditemukan tulisan yang berbicara kedaulatan Tuhan yang digali dari ketatanegaran asli Indonesia. Merupakan hal yang wajar apabila sampai sekarang terdapat perbedaan, pemikiran kedaulatan Tuhan dalam kehidupan kenegaraan Indonesia. Terlebih saling silih sangka kearah yang kurang dalam kehidupan beragama.

Pada masa sekarang saat yang tepat melihat kedaulatan Tuhan sebagai salah satu kedaulatan yang tidak dapat dihilangkan dalam membangun negara sebagaimana yang dikatakan Ismail Sunny. ${ }^{6}$ Bukti kedaulatan Tuhan dalam ketatanegaraan Indonesia dapat dilihat dari UUD 1945 masih menggunakan nsakah asli.7 Penelisikan kedaulatan Tuhan pada dasarnya secara gamblang dapat dilihat dari sejarah Ken Arok yang merupakan raja Tumapel telah berhasil menggunakan kedaulatan Tuhan untuk mendapatkan kekuasaan atas Kediri. Maka yang menjadi pertanyaan sejauhmana eksistensi kedaulatan Tuhan di Indonesia dalam pergumulan ketatanegaraan yang mendasari nilai-nilai ketuhanan.

\footnotetext{
Jimly Asshiddiqie, Gagasan Kedaulatan Rakyat dalam Konstitusi Dan Pelaksanaannya Di Indonesia:Pergeseran Keseimbangan Antara Individualisme Dan Kolektivisme Dalam Kebijakan Demokrasi Politik Dan Demokrasi Ekonomi Selama Tiga Masa Demokrasi 1945-1980-an, (Jakarta: Disertasi Pada Fakultas Pasca Sarjana Universitas Indonesia, 1993 ), hlm. 61

2 Krisna Bayu Adji dan Sri Wintala Achmad, Sejarah Panjang Perang Jawa di Bumi Jawa: dari Mataram Kuno Hingga Pasca Kemerdekaan Republik Indonesia, Cetakan 1, (Araska Publisher: Yogyakarta, 2014), hlm 72.

3 Lebih jelas lihat runutan tatanegara kerajaan di Indonesia, Krisna Bayu Adji dan Sri Wintala Achmad, Sejarah Panjang Perang Jawa di Bumi Jawa..., Ibid, hlm 13-188.

4 Mahkamah Konstitusi Republik Indonesia, Naskah Komprehensip Perubahan Undang-Undang Dasar Negara Republik Indonesia Tahun 1945:Latarbelakang, Proses dan Hasil Pembahasan 1999-2002 Buku VIII Warga Negara dan Penduduk, Hak Asasi Manusia dan Agama, Edisi Revisi, (Sekertariat Jenderal dan Kepaniteraan Mahkamah Konstitusi: Jakarta, 2010), hlm 85.

5 Bertepatan dengan kedatangan VOC, lihat Mahkamah Konstitusi Republik Indonesia, Naskah Komprehensip..., ibid, hlm 86 .

6 Jimly Asshiddiqie, Gagasan Kedaulatan Rakyat dalam Konstitusi Dan Pelaksanaannya Di Indonesia:Pergeseran Keseimbangan Antara Individualisme Dan Kolektivisme..., OP.Cit, hlm, 61.

7 Lihat amandement 1, 2, 3, dan 4 UUD 1945 terutama pasal yang berkenaan dengan agama.
} 


\section{Metodologi Penelitian}

Metode yang digunakan yakni dilakukan dengan cara mencari berbagai sumber bacaan baik yang berupa buku, jurnal, dan berita di internet. Melalui penelusuran literatur diharapkan dapat menemukan hubungan yang dapat dipertanggungjawabkan tentang kedaulatan Tuhan di Indonesia. Selain itu korelasi dalam pergumulan dalam kedaulatan Tuhan juga akan coba digambarkan melalui kalimat yang tersusun. Bantuan sejarah hukum dalam memecahkan masalah saat ini sangat diperlukan dimana keuntungan yang didapatkan yakni sebagai upaya mengambil kebijakan kearah yang lebih baik. ${ }^{8}$ Jenis penelitian sendiri menggunakan penelitian kualitatif deskriptif, dilakukan dengan cara mendeskripsikan pemikiran yang berkenaan dengan pokok bahasan. Analisis hukum normatif melalui aturan-aturan hukum formal yang dinilai mendukung pergumulan kedaulatan Tuhan kemudian mencoba menarik simpulan yang sesuai dengan rumusan masalah yang telah disajikan. Penulisan ini termasuk dalam kategori penelitian normatif hukum yang dilakukan melalui berbagai upaya untuk mengkaji dan menganalisis secara mendalam berbagai ketentuan hukum yang berkaitan dengan masalah penelitian (study of law in the book). Yakni meneliti secara literatur hal-hal yang berkaitan penulisan.

\section{Hasil dan Pembahasan}

\section{Pergumulan Kedaulatan Tuhan Ken Arok Awal Pemikiran Negara Kerajaan Nusantara dan Ilham Negara Kesatuan Republik Indonesia}

Kata pergumulan digunakan dibidang ketatanegaran Indonesia digunakan Jimly Asshiddiqie pada tahun 1996. ${ }^{9}$ Selain itu juga dalam konteks keagamaan digunakan oleh M. Baharudin. ${ }^{10}$ Pada dasarnya istilah pergumulan bagian seni beladiri, dan terdiri dari berbagai teknik untuk menangani lawan saat dipeluk atau dalam genggaman. Teknik-teknik pergumulan termasuk berbagai gerakan untuk mendapatkan posisi menguntungkan (misalnya guard atau mount), jatuhan, berbagai tindihan, kuncian sendi, dan kuncian rasa sakit. ${ }^{11}$

Pada berbagai seni beladiri Tiongkok ada sejenis sistem serupa pergumulan bernama chin na. Sistem ini menggunakan titik-titik akupresur untuk mendapatkan kuncian atau melumpuhkan lawan. Istilah tersebut dapat ditarik pengertian bahwa pergumulan merupakan seni atau cara untuk mendapatkan sesuatu dalam lingkup yang sama. Apa yang dilakukan Ken Arok merupakan pergumulan kedaulatan Tuhan untuk memenangkan kekuasaan atas Kediri dalam ranah ketatanegaran kerajaan.

Perlu juga diingat bahwa hukum sekarang mengalir dari sebelumnya atau hukum pada masa yang lampau, hal ini membuktikan bahwa hukum yang sekarang dibentuk dari masa yang lampau. ${ }^{12}$ Peperangan antara Tumapel dan Kediri tidak dapat dihindari, dan merupakan pergumulan kedaulatan Tuhan dalam rangka memperoleh kemenangan. Peperangan antara dua pasukan dari dua negara kerajaan terjadi di dekat desa Genter pada tahun 1222 M.13 Kutipan akan berakhirnya negara kerajaan Kediri yang dipimpin oleh Dandang Gendis ${ }^{14}$

\footnotetext{
\& Ketuhanan dihubungkan dengan ruang dan waktu yang merangkai kesejarahan dan kehidupan umat manusia masa lampau M. Baharudin, "Pergumulan Keagamaan di Dunia Barat", Jurnal Teologia Volume 25 Nomor 2, 2014, hlm 14. Satjipto Rahardjo, Ilmu Hukum, Cetekan enam, (Bandung: Citra aditya Bakti, 2006), hlm 356.

9 Jimly Asshiddiqie, Pergumulan Peran Pemerintah dan Parlemen dalam Sejarah: Telaah Perbandingan Konstitusi Berbagai Negara, (Jakarta: Universitas Indonesia Press, 1996).

10 M. Baharudin, “Pergumulan Keberagamaan di Dunia Barat”, Jurnal Teologi Volume 25 Nomor 2, 2014, hlm 1-23.

https://id.wikipedia.org/wiki/Pergumulan, diakses 20 Maret 2018.

2 Satjipto Rahardjo, Ilmu..., Op.Cit, hlm 256-257.

13 Slamet Mulyana, Nagarakretagama Tafsir dan Sejarahnya (Jakarta: Bhratara Karya Aksara, 1979), hlm 60. Lihat juga Feny Damayanti dan Suparwoto, "Pemerintahan Wisnuwardhana Ditinjua dari Segi Politik dan Keagamaan (1248-1268), Jurnal Pendidikan Sejarah AVATARA, Volume 4 Nomor 1, 2016, hlm 1-6.

14 Menurut negara Kertagama Kertajaya merupakan raja terakhir Kediri dengan gelar Sri Maharaja Sri Sarweswara Triwikramawatara Anindita Srenggalancana Digjaya Uttunggadewa. Sementara menurut serat Pararaton, Kerta
} 
terdapat dalam Serat Pararaton. ${ }^{15}$ Pergumulan kedaulatan Tuhan dalam ketatanegaraan kerajaan dapat dilihat dari kutipan dalam perang Tumapel dan Kediri.

Raja Dandang Gendis dari Daha berkata pada para Pendeta di seluruh negeri itu,"Wahai TuanTuan Pendeta pemeluk agama Siwa dan Budha! Kenapa Tuan-tuan tidak menyembah padaku. Bukankah aku adalah Bhatara Guru.

"Tuanku! Sejak jaman dulu tidak ada pendeta yang menyembah seorang raja"."Jika sejak dulu tidak ada seorang pendeta yang menyembah raja, sekarang hendaklah tuan-tuan menyembahku! Jika tuan-tuan tidak tahu kesaktianku, sekarang akan aku tunjukan buktinya".Raja Dandang Gendis memancangkan sebatang tombak di atas tanah, kemudian dia duduk di ujung tombak itu, seraya berkata "Tuan-tuan pendeta! Lihatlah kesaktianku!". Disaat raja Dandang Gendis duduk di ujung tombak itu senampak Bhatara Guru yang berlengan empat dan bermata tiga. Dengan sikap arogan, Dandang Gendis memerintahkan pada semua pendeta untuk menyembahnya. Namun semua pendeta itu tidak mematuhi perintah sang raja. Para pendeta yang menentang perintah Dandang Gendis itu kemudian mencari perlindungan ke Tumapel. Menghamba pada Ken Arok itulah asal mula Tumapel tidak mau tunduk pada negara Daha. ${ }^{16}$

Tak lama kemudian, Dandang Gendis mendengar kalau Ken Arok sudah menjadi raja Singosari. Tidak hanya itu, Dandang Gendis mendengan kalau Ken Arok hendak menyerang Daha. Maka Dandang Gendis berkata, "Tak ada yang mampu meruntuhkan negaraku. Tak ada yang sanggup mengalahkanku, selain Bhatara Guru yang turun dari angkasa".

Perkataan Dandang Gendis kemudian disampaikan oleh pendeta pada Ken Arok. Sang Amurwabumi berkata, "wahai para pendeta pemeluk Siwa dan Budha restuilah aku untuk bergelar Bhatara Guru".

Para pendeta Siwa dan Budha merestui permohonan Ken Arok. Sejak itu, Ken Arok bergelar Bhatara Guru. Selanjutnya Ken Arok pergi menyerang Daha. ${ }^{17}$

Dandang Gendis mendengar bahwa sang Amurwarbumi telah datang menyerang Daha. Dandang Gendis berkata, "Aku akan dikalahkannya, karena Ken Arok sedang dilindungi Dewa".

Sekarang tentara Tumapel bertempur welawan tentara Daha. Mereka berperang disebelah utara desa Genter. Mereka sama-sama bernyali tinggi. Mereka saling bunuh. Hingga terdesaklah tentara Daha. Adik raja Dandang Gendis yang bernama Mahisa Walungan gugur sebagai pahlawan. Demikian juga menterinya yang bernama Gubar Baleman. Mereka gugur karena diserang tentara Tumapel yang menyerupai banjir besar dari puncak gunung. Sekarang tentara Daha terpaksa berlari tunggang langgang. Karena yang menjadi senopati telah gugur di medan laga, maka bubarlah tentara Daha seperti lebah. Mereka berlari terbirit-birit seperti sekawanan rusa yang diburu harimau lapar. Mencabut semua payung. Tak ada yang sanggup melakukan perlawanan.

Raja Dandang Gendis mundur dari pertempuran. Mengungsi kea lam dewa. Tergantunggantung diangkasa bersama kuda, pembawa payung, serta pembawa tempat sirih, tempat air minum, dan tikar. Sungguh Daha dapat ditaklukan oleh Tumapel. Sementara adik-adik Dandang

Jaya Bernama Dandang Gendis. Krisna Bayu Adji dan Sri Wintala Achmad, Sejarah Panjang Perang Jawa di Bumi Jawa..., Op.Cit, hlm 69.

15 Krisna Bayu Adji dan Sri Wintala Achmad, Sejarah Panjang Perang Jawa di Bumi Jawa..., Ibid hlm 70.

16 Kepemimpinan tokoh Arok dalam novel Arok Dedes karya Pramoedya Ananta Toer mencerminkan seorang pemimpin yang tangguh dan adil. Ia merupakan pemimpin sudra yang berhati ksatria dan berjiwa brahmana, artinya ia adalah tokoh pejuang masyarakat kelas bawah yang gagah berani dan memperjuangkan kesetaraan masyarakat secara menyeluruh. Ia berusaha merangkul semua komponen masyarakat dari kaum sudra sampai kaum brahmana untuk bersama-sama memperjuangkan hak-hak mereka sebagai manusia. I Wayan Nitayadnya, "Kepemimpinan Arok dari Persefektif Asthabrata dalam Novel Aro Dedes Karya Pramoedya Ananta Noer". Jurnal Widyariset, Volume 16 Nomor 1, 2013, hlm 81-91.

17 ...."Dengarkan kalian semua, sejak detik ini, dalam kesaksian Hyang Bhatara Guru, yang terpadu dalam Brahma, Syiwa, dan Wisynu dengan semua saktinya, aku turunkan pada anak ini nama yang akan membawanya pada keyataan sebagai bagian dari cakrawarti. Kenyataan itu kini masih membara dalam dirimu, Arok" Pramudya Ananta Toer dalam I Wayan Nitayadnya, Kepemimpinan Aro dari Persefektif.. Ibid, hlm 87. 
Kosmik Hukum Vol. 20 No. 2 (2020): 128-139

E-ISSN: 2655-9242 | P-ISSN: 1411-9781

DOI: $10.30595 /$ kosmikhukum.v20i2.7477

Gendis, Dewi Hasin dan Dewi Paja yang tahu bahwa kakanya telah berada di alam dewa dan bergantung-gantung diangkasa sontak menghilang bersama istananya. ${ }^{18}$

Arok pada saat kecil merupakan anak yang cerdas dan gesit. Kecerdasan yang dimilikinya melebihi anak seusianya. Kepadanyalah harapan kaum brahmana ditumpukan untuk dapat mengembalikan kejayaan kaum Syiwa yang ditindas oleh pihak Kerajaan Tumapel penganut Wisnu. Amanat para brahmana yang dibebankan di pundak Arok terlukis dalam kutipan berikut.

"Dengan namamu yang baru, Arok, Sang Pembangun, kau adalah garuda harapan kaum brahmana." Arok masih tetap berlutut. Malam makin sunyi diselingi gelepar kalong menyerbui tajuk pepohonan buah. "Garuda harapan kaum brahmana," ia mengulangi pelan. "Para dewa tidak ditunjukkan padamu jadi talapuan," ulangnya lagi. "Kau akan kembalikan cakrawarti Bhatara Guru Sang Mahadewa Syiwa." "Kembalikan keseimbangan Jagad Pramudita." "Kembalikan keseimbangan Jagad Pramudita"19

Tunggul Ametung bertindak sewenangwenang sehingga rakyatnya semakin menderita. Hak rakyat dirampas dan mereka diwajibkan bekerja (kerja rodi) untuk kepentingan pihak kerajaan. Dedes yang terkenal karena kecantikannya dinikahi secara paksa Tunggul Ametung. Hal ini yang menyebabkan kaum brahmana membenci. Kaum brahmana memerintahkan kepada Arok untuk menghentikan kelakuan buruk Tunggul Ametung.

Teori Kedaulatan Tuhan dianggap sebagai teori kedaulatan yang pertama dalam sejarah. ${ }^{20}$ Kedaulatan Tuhan mengajarkan bahwa negara dan pemerintah mendapatkan kekuasaan tertinggi dari Tuhan sebagai asal segala sesuatu (Causa Prima). ${ }^{21}$ Menurut teori kedaulatan Tuhan, kekuasaan berasal dari Tuhan yang diberikan kepada tokoh-tokoh negara terpilih, yang secara kodrati ditetapkan-Nya menjadi pemimpin negara dan berperan selaku wakil Tuhan di dunia. Teori kedaulatan Tuhan umumnya dianut oleh raja-raja yang mengaku sebagai keturunan dewa, misalnya dalam sejarah para raja Mesir Kuno, Kaisar Jepang, Kaisar China, Raja Belanda ( Bidde Gratec Gods, kehendak Tuhan), Raja Ethiopia (Haile Selas, Singa penakluk dari suku Yuda pilihan Tuhan). Ken Arok sebagai peletak negara Indonesia dapat dikatakan melekat pada dirinya akan nilai-nilai ketuhanan. ${ }^{22}$ Terlepas dari latarbelakang Ken Arok yang banya diceritakan dalam berbagai literatur.

Demikian pula dianut oleh para raja Jawa zaman Hindu yang menganggap diri mereka sebagai penjelmaan Dewa Wisnu. Ken Arok bahkan menganggap dirinya sebagai titisan Brahmana, Wisnu, dan Syiwa sekaligus. Ketika menjabat sebagai raja Ken Arok menggunakan gelar Abiseka Ranggah Rajasa Sang Girinathaputra atau Sri Rajasa Bhatara Sang Amurwabumi. Sebagai titisan Tuhan Ken Arok memiliki orientasi pada kerakyatan yang setia pada janji, berwatak tabah, kokoh, toleran, dan senantiasa bersifat sosial.23 Walaupun demikian, sebagai wakil Tuhan di dalam tata negara kerajaan Singasari, Ken Arok adalah manusia biasa yang tidak luput dari kesalahan dalam mengembangkan kerajaannya. Ken Arok, sendiri dapat

18 Apabila ditelusuri proses kematian Dandang Gendis merupakan upacara kematian yang identik dengan kebudayaan Jawa. Walaupun kata-kata seolah-oleh mengandung kesaktian.

19 I Wayan Nitayadnya, “Kepemimpinan Arok dari Persefektif..., Ibid, hlm 84.

20 Anggapan tersebut pada dasarnya belum tentu kebenarannya, namun akibat pendapat dari para sarjan hukum dan sarjana politik menjadikan teori kedaulatan Tuhan dianggap sebagai teori pertama tentang lahinya kedaulatan. Perlu juga dikatahui bahwa setiap Negara tidak harus melihat teori tersebut sebagai yang sama, melainkan hanya sebagai pengembangan kenegaraan saja.

21 Moh. Kusnardi dan Bintan R. Saragih, Ilmu Negara, (Jakarta : Gaya Media Pratama, 2000), hlm 123.

22 Sarip, Hukum Tata Negara Materil, (Cirebon: Elsi Pro, 2018), hlm 145-147.

23 Krisna Bayu Adji dan Sri Wintala Achmad, Sejarah Perang di Bumi Jawa Dari Mataram Kuno Hingga Pasca Kemerdekaan Republik Indonesia, Araska Publisher, Cetakan I, (Yogyakarta: 2014), hlm 79. Baca juga, Sri Wintala Achmad, Babad Tanah Jawa (Dari Nabi Adam Hingga Mataran Islam, Araska, (Yogyakarta: 2013). Baca juga Krisna Bayu Adji dan Sri Wintala Achmad, Singasari Dan Kitab Para Datu, Araska, (Yogyakarta: 2013). Lihat juga I Wayan Nitayadnya, “Kepemimpinan Aro dari Persefektif..., Op.Cit, hlm 87 
dikatakan sebagai seorang seniman politik, adapun bukti teori kedaulatan tuhan yang dibuktikan melalui seni berpolitik sendiri antara lain: 1) Menikahi puteri petapa, yang merupakan titisan dewata; 2) Mendengar pendapat para pemuka agama, sebagai bukti akan adanya kekuatan Tuhan dalam memimpin negara kerajaan; 3) Mengatasnamakan Tuhan untuk memperluas kekuasaannya; dan lain-lain. ${ }^{24}$

Dalam rangka mendapatkan gelar sebagai Raja Singasari, Ken Arok pada dasarnya melakukan 'delik tata negara kerajaan'. ${ }^{25}$ Delik tata negara kerajaan yang dilakukan Ken Arok telah mendapatkan dukungan dari para pemuka agama Hindu dan Budha. ${ }^{26}$ Delik tata negara kerajaan dilakukan Ken Arok terhadap Kertajaya yang berkedudukan sebagai raja Kediri. Menurut Nagarakretagama, Kertajaya merupakan raja terakhir Kediri dengan gelar Sri Maharaja Sri Sarweswara Triwikramawatara Anindita Srenggalancana Uttunggadewa. Sementara menurut Serat Pararaton, Kertajaya bernama Prabu Dandang Gendis. Bukti keberadaan nama Kertajaya dapat ditemukan pada Prasasti Galunggung (1194M), Prasasti Kamulan (1194M), Prasasti Palah (1197M), dan Prasasti Wates Kulon (1205). ${ }^{27}$

Ken Arok sebagai penguasa Tumapel yang merupakan bawahan dari Kediri telah melakukan delik tata negara kerajaan. Apa yang dilakukan oleh Ken Arok dalam istilah Hukum Internasional dengan sebutan "belligerent". ${ }^{28}$ Gerakan Ken Arok untuk mendapatkan kekuasaan dengan cara melakukan delik tata negara kerajaan, dilegalkan secara hukum negara kerajaan pada saat itu, maupun Hukum Internasional masa sekarang. Ken Arok telah memenuhi syarat untuk melakukan delik tata negara kerajaan, sebagai "belligerent", adapun syarat tersebut yakni:

1. Gerakan Ken Arok dalam melakukan 'delik tata negara kerajaan' terorganisasikan secara rapi dan teratur di bawah pimpinannya yang jelas yakni dibawah komando Ken Arok serta para pemuka agama Hindu dan Budha;

2. Ken Arok memiliki tanda pengenal sebagai identitasnya yakni tanda Tumapel;

3. Dalam melakukan 'delik tata negara kerajaan' Ken Arok telah menguasai wilayah Tumapel secara efektif, wilayah tersebut berada dalam kekuasaan Ken Arok;

4. Ken Arok dalam melakukan 'delik tata negara kerajaan' dari rakyat di wilayah yang didudukinya bahkan dari para pemuka agama Hindu dan Budha dari daerah Kediri (Dhaha). ${ }^{29}$

Tindakan Ken Arok sendiri dalam teori kedaulatan Tuhan dan sebagai belligerent dikatakan sebagai delik tata negara kerajaan, memiliki konsekuensi sebagai akibat yang dilakukannya, adapun konsekuensi dapat berupa:

1. Apabila delik tata negara kerajaan yang dilakukan oleh Ken Arok berhasil, maka sebagai konsekuensinya Ken Arok mendapatkan kedudukan dan dapat membentuk hukum negara yang bersangkutan;

24 Bandingkan dengan I Wayan Nitayadnya, Arok dianggap sebagai garuda (simbol pelindung) oleh kaum brahmana dan rakyat Tumapel yang tertindas. I Wayan Nitayadnya, "Kepemimpinan Aro dari Persefektif..., Ibid, hlm 87

25 Delik tata negara kerajaan yang dimaksudkan dalam tulisan ini pada dasarnya adalah sama dengan delik tata negara, ditambahkan kata kerajaan lebih disebabkan pada jaman tersebut belum mengenal istilah negara seperti yang dikenal sekarang, melainkan yang dikenal yakni kerajaan.

26 Sebelum menjadi Singasari Ken Arok sebagai pemimpin Tumapel bawahan kerajaan Kediri, Ken Arok memimpin Tumapel setelah berhasil mempersunting Ken Dedes dan membunuh Tunggul Ametung.

27 Krisna Bayu Adji dan Sri Wintala Achmad, Sejarah Perang di Bumi Jawa..., Op.Cit, hlm 69-70.

28 Menurut Hukum Perang, pemberontak dapat memperoleh kedudukan dan hak sebagai pihak yang bersengketa (belligerent) dalam keadaan-keadaan tertentu. Keadaan tertentu ini, ditentukan oleh pengakuan pihak ketiga bagi pemberontak atau pihak yang bersengketa. Likadja Frans E., Frans Bessie Daniel, Desain Instruksional Dasar Hukum Internasional, Ghalia Indonesia, Jakarta: 1988), hlm 92.

29 Lihat dan bandingkan dengan I Wayan Parthiana, Masalah-Masalah dalam Hukum Internasional dan Hukum Nasional Indonesia, Binacipta, Bandung: 1987), hlm 87. Baca juga Slamet Mulyana, Runtuhnya Kerajaan HinduJawa Dan Timbulnya Negara-Negara Islam Di Nusantara, LKIS, (Yogyakarta: 2005). 
2. Apabila yang dilakukan Ken Arok tidak berhasil dalam melakukan delik tata negara kerajaan, maka sebagai konsekuensinya Ken Arok akan di hukum oleh Kediri atau Kertajaya sebagai raja pada saat itu.

Sebagai seorang yang telah melakukan delik tata negara kerajaan Ken Arok mendapatkan kedudukan sebagai penguasa. Sebutan perbuatan Ken Arok terhapat Kediri disebut sebagai Belligernt, tapi tindakan Ken Arok dalam menggulingkan kekuasaan Tunggul Ametung bukan disebut sebagai Belligernt, sebab tindakannya tidak memenuhi sebagai Belligernt, melainkan hanya merupakan pemberontakan biasa. ${ }^{30}$ Walaupun tindakannya dapat dikatakan sebagai delik tata negara kerajaan. Dikatakan demikian lebih dibuktikan bahwa Ken Arok sebagai rakyat biasa ingin menjadi raja, dengan tidak memiliki wilayah tertentu. Begitu juga apabila tindakan Ken Arok dikatakan sebagai 'Kudeta' tidak juga termasuk, sebab Ken Arok pada saat itu bukanlah ponggawa Tumapel. Kemungkinan besar apa yang dilakukan Ken Arok terhadap Tumapel merupakan cara memperoleh kekuasaan melalui cara yang disahkan pada saat itu. ${ }^{31}$

Hal berbeda dalam teori kedaulatan Tuhan di tanah Jawa telah ditunjukan oleh Raja Airlangga di nama pada tahun 1042 Masehi Raja Airlangga yang menganggap dirinya sebagai turunan Tuhan, Erlangga tidak mau ikut campur dalam urusan negara. ${ }^{32}$ Airlangga lebih memilih untuk menjadi petapa yang jauh dari dunia pana. Sebagai buktinya bahwa teori kedaulatan Tuhan tidak selamanya menjadikan seseorang untuk memimpin negara melainkan menyadarkannya untuk selalu mendekatkan diri pada Sang Pencipta. Di dalam tata kerajaan di Indonesia, teori kedaulatan Tuhan sendiri mengalami kehancuran ketika seseorang dengan menggunakan dalih-dalih Tuhan untuk menakuti orang-orang disekitarnya. Sebagaimana yang dilakukan oleh Kertajaya, bermula dari laporan para pendeta Hindu dan Budha yang tidak menyukai sikap arogansi Kertajaya, para pendeta melaporkan pada Ken Arok untuk menggulingkan kekuasaan Kertajaya pada tahun 1222 Masehi. Sesudah Kertajaya Wafat, Kediri mengalami akhir riwayatnya sebagai negara kerajaan yang berdaulat. ${ }^{33}$

\section{Kedaulatan Tuhan Penguatan Ketatanegaran Indonesia Sebagai Negara Modern yang Berketuhanan}

Di dunia Barat teori kedaulatan Tuhan dipelopori antara lain: Augustinus (354-430) ${ }^{34}$, Thomas Aquino (1215-1274), juga F. Hegel (1770-1831) dan F.J. Stahl (1802-1861). Karena berasal dari Tuhan, maka kedaulatan negara bersifat mutlak dan suci. Seluruh rakyat harus setia dan patuh kepada raja yang melaksanakan kekuasaan atas nama dan untuk kemuliaan Tuhan. Menurut Hegel, raja adalah manifestasi keberadaan Tuhan. Maka, raja/ pemerintah selalu benar, tidak mungkin salah. Dalam kedadaan demikian ternyata pemaknaan the King can't do wrong, dijadikan bahan pembenar untuk melakukan tindakan-tindakannya. ${ }^{35}$

Lihat Sarip, Pengantar Hukum Internasional, (Kuningan: Uniku Press, 2016), hlm 121-148.

Bandingkan dengan Krisna Bayu Adji dan Sri Wintala Achmad, Sejarah Perang di Bumi Jawa..., Op.Cit, hlm 89.

32 Menurut Prasasti Cane yang berangka tahun 1021 Masehi dan Prasasti Turun Hyang yang berangka tahun 1035 Masehi, selama menjadi petapa menggunakan gelar Dewi Kilisuci atau gelar Resi Airlangga Jatiningrat (versi Serat Calon Arang), Resi Gentayu (versi Babad Tanah Jawa), atau Resi Aji Paduka Mpungku Sang Pinaka Citraning Bhuana (versi Prasasti Gandhakuti yang berangka tahun 1042 Masehi).

33 Bukti nyata tentang kehancuran teori kedaulatan tuhan di tanga Kertajaya dibuktikan dengan Serat Pararaton yang menyatakan Kertajaya mati di kayangan atau alam dewa. Selain itu argument tersebut diperkuat oleh para sejarawan yang dimaksud dengan alam kayangan atau alam dewa dimaknai bahwa raja Kediri itu meninggal dirungan candi dengan cara moksa, kematian dengan tanpa meninggalkan jasadnya, lihat Krisna Bayu Adji dan Sri Wintala Achmad, Sejarah Perang..., Op.Cit, hlm 73.

34 Agustinus juga berpendapat bahwa kedudukan greja yang dipimpin Sri Paus lebih tinggi dari kedudukan Negara yang di pimpin oleh raja ,karena paus merupakan wakil dari tuhan. Agustinus membagi ada dua macam Negara yaitu Civitate Dei (Kerajaan Tuhan). Civitate Diabolis/Terrana (Kerajaan Setan) yang ada di dunia fana. Lihat Moh. Kusnardi dan Bintan R. Saragih, Ilmu Negara, Gaya Media Pratama, (Jakarta : 2000) hlm 48-49.

35 Pendapat the king can't do wrong atau seorang penuasa tidak dapat dipersalahkan, sampai sekarang berkembang dalam pemikiran negara hukum modern. Sebagai bukti dapat dilihat dari berbagai konstitusi di dunia sebagai contoh UUD 1945 terutama Pasal 12 dan Pasal 22. Selin itu juga seiring dengan perkembangan jaman konsep tersebut pendapat perlawanan dengan konsep vox populi vox dei yang mengidentikan bahwa suara tuhan adalah 
Pendapat Hegel pada dasarnya tidak dapat diiyakan begitu saja, sebab di negara kerajaan Jawa dalam membentuk hukum negara telah terjadi pertarungan yang sangat dahsyat antara dua kedaulatan Tuhan yakni kedaulatan Tuhan yang dianut oleh Kertajaya dan kedaulatan Tuhan yang dianut oleh Ken Arok. Artinya pendapat Hegel tersebut yang dimanifestasikan pada seorang raja yang pongah tidaklah benar. Adapun kutipan pertarungan kedua raja yang memegang teori kedaulatan Tuhan dalam membentuk hukum negara adalah sebagai berikut:

Raja Kertajaya dari Kediri berkata "Wahai tuan-tuan pendeta pemeluk agama Siwa dan Budha, Kenapa tuan-tuan tidak menyembah padaku. Bukankah aku adalah Bhatara Guru" ...., "Tak ada yang mampu meruntuhkan negaraku, tak ada yang sanggup mengalahkanku, selain Bhatara Guru yang turun dari angkasa"......, Ken Arok berkata "Wahai, para pendeta pemeluk agama Siwa dan Budha restuilah aku untuk menjdi Bhatara Guru" Namun para pendeta menjawab atas pernyataan Kertajaya dengan mengatakan "Tuanku? Sejak jaman dulu tidak ada seorang pendeta yang menyembah raja, 36 "Kertajaya kemudian berkata kembali, jika sejak dulu tidak ada seorang pendeta yang menyembah seorang raja, sekarang hendaklah tuan-tuan menyembahku. Jika tuantuan tidak tau kesaktianku maka akan ku tunjukan sekarang..." Tak ada yang bisa mengalahkanku kecuali bhatara guru yang turun langsung dari langit untuk mengalahkanku...."37 Sementara adik-adik Kertajaya yakni: Dewi Amisam, Dewi Hasin, dan Dewi Paja yang tahu kalau kakaknya telah berada di alam dewa dan menggantung-gantung di angkasa sontak menghilang bersama dengan istananya.

Dari kutipan tersebut dapat diartikan bahwa ketika teori kedaulatan tuhan diberlakukan atau digunakan secara berlebihan, justru akan mendapatkan kesulitan-kesulitan apalagi sampai menentang para pemuka agama atau dengan istilah lain menentang aristokrat. Selain itu juga apabila dicermati apa yang dikatakan oleh para pendeta Hindu Budha pada dasarnya ada perbedaan, hal ini sejalan dengan pendapat jaman pertengahan yakni Agustinus. Agustinus ${ }^{38}$ dalam buku De Civita te Dei tersebut Augustinus menyebutkan adanya dua macam negara, yaitu: Pertama Civitas Dei, atau negara Tuhan. Negara ini sangat dipuji oleh Augustinus, karena ini adalah negara yang diangan-angankan, dicita-citakan oleh Agama. Kedua Civitas Terrena, atau Diaboli, atau negara Iblis, atau negara Duniawi. Negara ini sangat dikecam dan ditolak oleh Augustinus. Negara yang paling baik itu adalah negara Tuhan, akan tetapi negara ini tidak akan pernah tercapai di dunia ini, tetapi semangatnya dimiliki oleh sebagian dari orang-orang di dunia ini, dan mereka ini harus selalu berusaha untuk mencapainya.

Ternyata apa yang terdapat dalam perbagai literatur telah membuktikan bahwa tentang siklus teori kedaulatan tidak selamanya berjalan sesuai dengan ketentuannya. Melainkan suatu teori kedaulatan dibangun dan runtuh dapat disebabkan oleh teori itu sendiri atau kemunculan teori yang lain. Seperti pertarungan yang dilakukan Kertajaya dan Ken Arok, bukti nyata tentang kehancuran teori kedaulatan Tuhan oleh teori kedaulatan tuhan yang kemudian melahirkan hukum negara di bawah pemerintahan Ken Arok. Begitu juga apa yang dilakukan oleh Airlangga dengan cara memisahkan diri dari urusan keduniaan atau urusan negara dengan agama.

Hal ini sejalan dengan pandangan C.F. Strong yang pada dasarnya suatu adat atau kebiasaan dapat digunakan sebagai sumber hukum dalam arti materil. ${ }^{39}$ Ken Arok yang telah

suara rakyat. Lihat dan bandingkan dengan I Wayan Nitayadnya, "Kepemimpinan Aro dari Persefektif..., Op.Cit, 87-89.

36 Krisna Bayu Adji dan Sri Wintala Achmad, Sejarah Perang..., Op.Cit, hlm 70-72.

37 Krisna Bayu Adji dan Sri Wintala Achmad, Sejarah Perang...,Ibid, hlm 71.

38 Augustinus hidup pada tahun 354 - 430. ia adalah seorang Kristen. Ia menulis buku yang diberi nama De Civita te Dei, tentang negara Tuhan.

39 C.F Strong, Konstitusi-konstitusi Politik Modern Kajian Tentang sejarah dan Pembentukan Konstitusi-Konstitusi Dunia, Terj. SPA Teamwork, Cetakan-1, Nuansa dan Nusamedia, (Bandung: 2004), hlm 8. Lihat juga R. Soeroso, 
berhasil merebut Kediri merupakan suatu bentuk sumber hukum ketatanegaraan Singasari dalam pandangan teori kedaulatan raja. Ken Arok telah melahirkan hukum negara kerajaan Singasari terhadap negara kerajaan Kediri yang telah ditaklukannya. Apa yang telah dilakukan Ken Arok dalam istilah hukum tata negara dikenal dengan sebutan aneksasi dan fusi. ${ }^{40}$ Dikatakan bahwa Ken Arok telah memadukan kedua terbentuknya negara baik secara aneksasi dan fusi, yakni dengan wafatnya Kertajaya merupakan akhir pemerintahan kerajaan Kediri pada tahun 1222 Masehi, sementara Ken Arok yang memerintah Tumapel dengan ditaklukannya Kediri berubah menjadi negara kerajaan Singasari. ${ }^{41}$

Pada dasarnya Tumapel sendiri merupakan bagian wilayah Kediri, semasa diperintah oleh Tunggul Ametung. Tunggul Ametung sendiri merupakan tokoh yang disebutkan dalam Serat Pararaton sebagai Adipati Tumapel yang dibunuh oleh Ken Arok. Dalam rangka memuluskan niatnya menguasai Tumapel, Ken Arok sendiri dapat dikatakan menggunakan teori kedaulatan tuhan yakni dengan cara menikahi puteri seorang petapa yakni Ken Dedes. Apabila ditelusuri Teori kedaulatan Tuhan versi Ken Arok sendiri seseorang akan menjadi seorang raja besar apabila berhasil menikahi seorang perempuan yang memiliki keturunan dewata. Titisan dewata akan turut serta membantu kesuksesnya dalam memerintah negara dan menciptakan hukum yang adil bagi masyarakatnya. Melalui 'politik perkawinan' 42 ternyata Ken Arok dapat menjadi raja Singasari, walaupun cara yang dilakukannya tidaklah mulus, sebab Ken Arok sendiri harus mengorbankan suami dari seorang yang putri keturunan dewata. ${ }^{43}$ Selain itu, bukti teori kedaulatan Tuhan sendiri pada masa Ken Arok, setelah berhasil membunuh Tunggul Ametung, Ken Arok kedatangan para Pendeta Hindu dan Budha dari Kediri untuk membantunya.

Selain bukti teori kedaulatan Tuhan yang diterapkan oleh Ken Arok untuk memperkuat kekuasaannya, di jaman modern juga, teori kedaulatan Tuhan dipraktikan oleh Soekarno semasa Orde Lama (ORLA). Sebagai bukti teori Kedaulatan Tuhan pada masa Soekarno datang dari menteri agama Republik Indonesia yang pada saat itu dijabat oleh K.H. Wahid Hasyim, yang menganggap penting dibangun Masjid megah sebagai rasa syukur atas kemerdekaan Indonesia dalam perjuangan melawan penjajah. ${ }^{44}$ Pada tahun 1950, dalam pemilihan lokasi sendiri Soekarno sempat berbeda pendapat dengan Hatta.

Hatta berpendapat bahwa masjid harus dibangun ditempat yang dekat dengan penduduk, sehingga Hatta mengusulkan pembangunan Masjid di jalan Tamrin, yang kini ditempati Hotel Indonesia (HI). Alasan Hatta berdekatan dengan berdekatan dengan pemukiman penduduk. Tetapi, Soekarno kukuh pada pendapatnya bahwa Masjid harus dibangun di atas taman Wihelmina, di lokasi bekas Benteng Belanda (Frederik Hendrik), yang dibangun oleh Gubernur Jenderal Van Den Bosch pada tahun 1834, lokasi itu tepatnya di antara jalan Perwira, jalan Lapangan Banteng, jalan Katedral, dan jalan Veteran. ${ }^{45}$

Pengantar Ilmu Hukum, Edisi.1, Cetakan- 4, Sinar Grafika, (Jakarta: 2001), hlm 117. Lihat juga Darji Darmodiharjo, Pokok-Pokok Filsafat Hukum, PT. Gramedia Pustaka Utama, (Jakarta: 2002) hlm 210.

40 Aneksasi adalah Suatu daerah/negara yang diambil alih (dicaplok) oleh bangsa lain, kemudian di wilayah itu berdiri negara. Contoh : Israel tahun 1948. Beberapa negara mengadakan peleburan menjadi satu negara baru. Contoh : Kerajaan Jerman (1871), Vietnam (1975), Jerman (1990). Tapi, apa yang dilakukan oleh Ken Arok merupakan perpaduan antara aneksasi dan fusi.

41 Selagi lima tahun menjadi Raja menurut Pararaton, Anusapati naik tahta sebagai raja Singasari kedua pada tahun 1227 Masehi.

42 Penulis sendiri sengaja menggunakan tanda (') pada 'politik perkawinan', hal ini bermaksud, ada suatu cara untuk memperoleh kekuasaan disela-sela kedaulatan yakni salah satunya melalui politik perkawinan, sekarang 'politik perkawinan' sendiri sangat efektif untuk melanggengkan kekuasaan, sebagai bukti pernikahan Putra Susilo Bambang Yudoyono dengan putrid Hatta Rajasa di era pemerintahan presiden SBY sebagai bukti nyata akan aplikasi politik tersebut.

43 Lihat Krisna Bayu Adji dan Sri Wintala Achmad, Sejarah Perang..., Op.Cit, hlm 78.

44 M. Sanusi, Kenangan Inspirasf Orde Lama dan Orde Baru (Operasi Trikora, Gelora Bung Karno, Swasembada Beras, Program Wajib Belajar,Transisi Orde Lama Ke Orde Baru, Pemikiran Bung Karno dan Pak Harto, Cet-1, Saufa, (Banguntapan Yogyakarta: 2014), hlm 56.

45 Perbedaan pendapat tentang lokasi Masjid antara Soekarno dan Hatta pada dasarnya merupakan perang politik, dimana rupanya Hatta menginginkan bahwa Masjid tersebut dapat dikunjungi dan dipenuhi oleh masyarakat Islam pada umumnya, namun Soekarno rupanya lebih memilih pada penghancuran bekas penjajahan dan 
Soekarno melandaskan nama Masjid pada filosofi pada makna Istiqlal yang berarti merdeka. Sebab ratu Wilhelmina sebagai representasi penjajahan di Bumi Indonesia harus dimusnahkan dengan masjid bernama kebebasan. Apabila dicermati apa yang terjadi di masa Soekarno bukti nyata bahwa teori kedaulatan Tuhan kembali dipraktikan, walaupun dalam gaya yang berbeda. Jaman Ken Arok menggunakan teori kedaulatan Tuhan untuk memperoleh kekuasaan. Sedangkan jaman Soekarno menggunakan teori kedaulatan Tuhan untuk meruntuhkan teori kedaulatan raja yang selama ini telah mengkungkung bangsa Indonesia. Dengan mempelajari tentang teori kedaulatan tuhan, maka dapat dikonsepkan tentang konsep delik tata negara dari sudut kedaulatan tuhan. Konsep delik tata negara berkaitan dengan kedaulatan tuhan yakni dengan menggunakan dalih-dalih tuhan untuk meruntuhkan kekuasaan atau mendapatkan kekuasaan, bahkan mempertahankan kekuasaan. Adapun sebagai konsekuensinya apabila delik tata negara dilakukan dengan selesai maka tidak akan mendapatkan hukuman, tapi apabila dilakukan tidak selesai akan mendapatkan hukuman sesuai dengan aturan-aturan hukum yang berlaku.

Soekarno sendiri rupanya sangat cerdas akan nilai ketuhanan yang menjiwai masyarakat Indonesia hal ini terbukti ketika menjawab pertanyaan Abdul Salim "kenapa Bung Karno lebih mengutamakan pembangunan Monas dibandingkan dengan Istiqlal". Bung Karno menjawab "saya dahulukan dan segerakan pembangunan Tugu Monas darpada Masjid Istiqlal karena saya yakin setelah saya tidak ada, pembangunan Masjid Istiqlal masih akan dilanjutkan oleh rakyat sampai jadi, sedangkan pembangunan Tugu Monas barangkali tidak dilanjutkan". ${ }^{46}$ Ternyata Bung Karno sangat menyadari bahwa rakyat Indonesia memiliki kedaulatan Tuhan dalam negara diatas segala-galanya jika dibandingkan dengan kedaulatan yang lainnya.

\section{Penutup}

Menelisik kedaulatan Tuhan dalam ketatanegaraan Kerajaan Indonesia dapat dilihat dari perkataan Ken Arok menyerang negara Kerajaan Kediri "Wahai para Pendeta pemeluk Siwa dan Budha. Restuilah Aku untuk bergelar Bhatara Guru". Teori kedaulatan Tuhan dianggap sebagai teori pertama dalam sejarah ketetanegaraan. Kedaulatan Tuhan memiliki peran yang sangat signifikan dalam memperoleh kekuasaan terlihat dari jaman ketatanegaraan kerajaan sampai pada politik modern. Pembahasan nilai-nilai ketuhanan ketatanegaraan modern Indonesia bertolak pada sisi agama yang coba diasingkan pada masa penjajahan Belanda. Di zaman penjajahan Belanda (Hindia Belanda) diadakan pembedaan golongan-golongan rakyat. Istilah pergumulan dapat ditarik pengertian bahwa pergumulan merupakan seni atau cara untuk mendapatkan sesuatu dalam lingkup yang sama. Apa yang dilakukan Ken Arok merupakan pergumulan kedaulatan Tuhan untuk memenangkan kekuasaan atas Kediri dalam ranah ketatanegaran kerajaan. Peperangan antara Tumapel dan Kediri tidak dapat dihindari, dan merupakan pergumulan kedaulatan Tuhan dalam rangka memperoleh kemenangan. Peperangan antara dua pasukan dari dua negara kerajaan terjadi di dekat desa.

Ken Arok sebagai penguasa Tumapel yang merupakan bawahan dari Kediri telah melakukan delik tata negara kerajaan. Apa yang dilakukan oleh Ken Arok dalam istilah Hukum Internasional dengan sebutan "belligerent". Gerakan Ken Arok untuk mendapatkan kekuasaan dengan cara melakukan delik tata negara kerajaan, dilegalkan secara hukum negara kerajaan pada saat itu, maupun Hukum Internasional masa sekarang. Selain bukti teori kedaulatan Tuhan yang diterapkan oleh Ken Arok untuk memperkuat kekuasaannya, di jaman modern juga, teori kedaulatan Tuhan dipraktikan oleh Soekarno semasa Orde Lama (ORLA). Sebagai bukti teori Kedaulatan Tuhan pada masa Soekarno datang dari menteri agama Republik Indonesia yang pada saat itu dijabat oleh K.H. Wahid Hasyim, yang menganggap

kemungkinan yang lebih penting adalah memotivasi para pegawai untuk selalu mendekatkan diri pada Tuhan. Terlepas dari kemungkinan politik yang ada pada saat itu, pada dasarnya apa yang dilakukan oleh Soekarno merupakan bentuk kekalahan kedaulatan raja oleh kedaulatan Tuhan.

46 Maulwi Sawlan dalam M. Sanusi, Kenangan Inspirasf Orde Lama dan Orde Baru..., Op.Cit, hlm 48. 
Kosmik Hukum Vol. 20 No. 2 (2020): 128-139

E-ISSN: 2655-9242 | P-ISSN: 1411-9781

DOI: $10.30595 /$ kosmikhukum.v20i2.7477

penting dibangun Masjid megah sebagai rasa syukur atas kemerdekaan Indonesia dalam perjuangan melawan penjajah.

\section{Daftar Pustaka}

Asshiddiqie, Jimly. 1993, Gagasan Kedaulatan Rakyat dalam Konstitusi Dan Pelaksanaannya Di Indonesia:Pergeseran Keseimbangan Antara Individualisme Dan Kolektivisme Dalam Kebijakan Demokrasi Politik Dan Demokrasi Ekonomi Selama Tiga Masa Demokrasi 1945-1980-an, Jakarta: Disertasi Pada Fakultas Pasca Sarjana Universitas Indonesia.

Asshiddiqie, Jimly. 1996, Pergumulan Peran Pemerintah dan Parlemen dalam Sejarah: Telaah Perbandingan Konstitusi Berbagai Negara, Jakarta: Universitas Indonesia Press.

Baharudin. M, "Pergumulan Keberagamaan di Dunia Barat", Jurnal Teologi Volume 25, Nomor 2, 2014.

Bayu Adji, Krisna. dan Wintala Achmad, Sri. 2013, Singasari Dan Kitab Para Datu, Yogyakarta: Araska.

Bayu Adji, Krisna. dan Wintala Achmad, Sri. 2014, Sejarah Panjang Perang Jawa di Bumi Jawa: dari Mataram Kuno Hingga Pasca Kemerdekaan Republik Indonesia, Cetakan 1, Yogyakarta: Araska Publisher.

Damayanti, Feny. dan Suparwoto, "Pemerintahan Wisnuwardhana Ditinjua dari Segi Politik dan Keagamaan (1248-1268), Jurnal Pendidikan Sejarah AVATARA, Volume 4 Nomor 1, 2016.

Darmodiharjo, Darji. 2002, Pokok-Pokok Filsafat Hukum, Jakarta: PT. Gramedia Pustaka Utama.

Frans E., Likadja. Bessie Daniel, Frans. 1988, Desain Instruksional Dasar Hukum Internasional, Jakarta: Ghalia Indonesia.

https://id.wikipedia.org/wiki/Pergumulan, diakses 20 Maret 2018.

Kusnardi, Moh. dan R. Saragih, Bintan. 2000, Ilmu Negara, Jakarta : Gaya Media Pratama.

Mahkamah Konstitusi Republik Indonesia, Naskah Komprehensip Perubahan Undang-Undang Dasar Negara Republik Indonesia Tahun 1945:Latarbelakang, Proses dan Hasil Pembahasan 1999-2002 Buku VIII Warga Negara dan Penduduk, Hak Asasi Manusia dan Agama, Edisi Revisi, (Sekertariat Jenderal dan Kepaniteraan Mahkamah Konstitusi: Jakarta, 2010).

Mulyana, Slamet. 1979, Nagarakretagama Tafsir dan Sejarahnya, Jakarta: Bhratara Karya Aksara.

Mulyana, Slamet. 2005, Runtuhnya Kerajaan Hindu-Jawa Dan Timbulnya Negara-Negara Islam Di Nusantara, Yogyakarta: LKIS.

Nitayadnya, I Wayan. "Kepemimpinan Aro dari Persefektif Asthabrata dalam Novel Aro Dedes Karya Pramoedya Ananta Noer". Jurnal Widyariset, Volume 16, Nomor 1, 2013,

Parthiana, I Wayan. 1987, Masalah-Masalah dalam Hukum Internasional dan Hukum Nasional Indonesia, Bandung: Binacipta.

Rahardjo, Satjipto. 2006, Ilmu Hukum, Cetakan enam, Bandung, Citra Adiya Bakti.

Sanusi, M. 2014, Kenangan Inspirasf Orde Lama dan Orde Baru (Operasi Trikora, Gelora Bung Karno, Swasembada Beras, Program Wajib Belajar,Transisi Orde Lama Ke Orde Baru, Pemikiran Bung Karno dan Pak Harto, Cet-1, Yogyakarta: Saufa, Banguntapan.

Sarip Sarip , 2016, Pengantar Hukum Internasional, Kuningan: Uniku Press.

Sarip Sarip, 2018, Hukum Tata Negara Materil, Cirebon: Elsi Pro.

Soeroso. R. 2001, Pengantar Ilmu Hukum, Edisi.1, Cetakan- 4, Jakarta: Sinar Grafika. 
Strong, C.F. 2004, Konstitusi-konstitusi Politik Modern Kajian Tentang sejarah dan Pembentukan Konstitusi-Konstitusi Dunia, Terj. SPA Teamwork, Cetakan-1, Bandung: Nuansa dan Nusamedia.

Wintala Achmad, Sri. 2013, Babad Tanah Jawa (Dari Nabi Adam Hingga Mataran Islam, Yogyakarta: Araska. 